\title{
Erratum to: Emotions on the loose: emotional contagion and the role of oxytocin in pigs
}

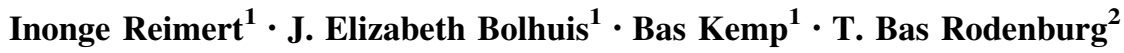

Published online: 13 June 2015

(c) Springer-Verlag Berlin Heidelberg 2015

\section{Erratum to: Anim Cogn (2015) 18:517-532 \\ DOI 10.1007/s10071-014-0820-6}

The original publication of this article unfortunately contained an error in Table 5. The superscript letters "a, b" were unintentionally omitted under the column head "Without naive pigs present" in the rows of "Standing alert", "Ears back", "Tail in curl" and "Tail wagging". The corrected table is given below.

The online version of the original article can be found under doi:10.1007/s10071-014-0820-6.

Inonge Reimert

inonge.reimert@wur.nl; inongereimert@gmail.com

1 Department of Animal Sciences, Adaptation Physiology

Group, Wageningen University, P.O. Box 338,

6700 AH Wageningen, The Netherlands

2 Department of Animal Sciences, Behavioural Ecology

Group, Wageningen University, P.O. Box 338,

$6700 \mathrm{AH}$ Wageningen, The Netherlands 
Table 5 Behavior of the training pigs during a positive and negative treatment in two situations: without the presence of two naive pen mates and in the presence of two naive pen mates in the test room

\begin{tabular}{|c|c|c|c|c|c|c|c|c|}
\hline & \multicolumn{3}{|c|}{ Without naive pigs present } & \multicolumn{2}{|c|}{ With naive pigs present } & \multicolumn{3}{|c|}{ Effects $^{1}$} \\
\hline & Positive & Negative & $\mathrm{T}^{2}$ & Positive & Negative & $\mathrm{T}^{2}$ & $S$ & TS \\
\hline \multicolumn{9}{|l|}{ Behavior } \\
\hline Standing alert ( $\%$ of time) & $0.3 \pm 0.1^{\mathrm{a}}$ & $32.9 \pm 3.1^{\mathrm{b}}$ & $* * *$ & $2.8 \pm 1.2^{\mathrm{a}}$ & $49.0 \pm 4.6^{\mathrm{c}}$ & $* * *$ & $* *$ & $*$ \\
\hline Escape attempts (\% of pens) ${ }^{3}$ & 0 & 62.5 & $* * *$ & 0 & 31.3 & $*$ & NS & - \\
\hline Play $(\% \text { of pens })^{3}$ & 100 & 0 & $* * *$ & 93.8 & 0 & $* * *$ & NS & - \\
\hline Urinating ( $\%$ of pens $)^{3}$ & 6.3 & $93.8^{\mathrm{g}}$ & $* * *$ & 0 & $62.5^{\mathrm{h}}$ & $* * *$ & NS & - \\
\hline Defecating (freq.) & $0.7 \pm 0.2$ & $4.7 \pm 0.5$ & $* * *$ & $0.7 \pm 0.3$ & $4.5 \pm 0.4$ & $* * *$ & NS & NS \\
\hline Exploring treatment door ( $\%$ of time) & $0.5 \pm 0.1$ & $3.4 \pm 0.7$ & $* * *$ & $0.4 \pm 0.2$ & $2.3 \pm 0.6$ & $* * *$ & + & NS \\
\hline \multicolumn{9}{|l|}{ Ear posture } \\
\hline Ears back (\% of time) & $1.9 \pm 0.7^{\mathrm{a}}$ & $17.3 \pm 4.7^{\mathrm{b}}$ & $* * *$ & $1.3 \pm 0.5^{\mathrm{a}}$ & $7.3 \pm 2.0^{\mathrm{c}}$ & $* *$ & * & + \\
\hline \multicolumn{9}{|l|}{ Tail postures } \\
\hline Tail in curl ( $\%$ of time $)$ & $87.3 \pm 3.5^{\mathrm{a}}$ & $99.8 \pm 0.2^{\mathrm{b}}$ & $* * *$ & $93.1 \pm 2.4^{\mathrm{c}}$ & $99.2 \pm 0.7^{\mathrm{b}}$ & $* *$ & NS & + \\
\hline Tail wagging ( $\%$ of time) & $12.3 \pm 3.4^{\mathrm{a}}$ & $0.1 \pm 0.0^{\mathrm{b}}$ & $* * *$ & $6.7 \pm 2.3^{\mathrm{c}}$ & $0.2 \pm 0.1^{\mathrm{b}}$ & $* * *$ & + & + \\
\hline Tail low (\% of time) & $0.4 \pm 0.2^{\mathrm{a}}$ & $0.1 \pm 0.1^{\mathrm{b}}$ & NS & $0.3 \pm 0.2$ & $0.6 \pm 0.5$ & NS & NS & NS \\
\hline \multicolumn{9}{|l|}{ Vocalizations (voc.) } \\
\hline Low-pitched voc. (freq.) & $0.2 \pm 0.2$ & $24.8 \pm 2.9$ & $* * *$ & & & & & \\
\hline High-pitched voc. (\% of pens) & 0 & 50.0 & $* *$ & & & & & \\
\hline Barks (\% of pens) & 87.5 & 0 & $* * *$ & & & & & \\
\hline
\end{tabular}

Means with different superscript letters differ significantly (a/b/c: $P<0.05, \mathrm{~g} / \mathrm{h}: P<0.1$ )

${ }^{1}$ Significance of effects of treatment (T), situation (S) and their interaction (TS) is indicated: *** $P<0.001 ; * * P<0.01 ; * P<0.05$;

${ }^{+} P<0.10 ;$ NS $P \geq 0.10 ;-$ no statistical analysis performed

2 These treatment effects belong to the first and second situation, respectively. Treatment effects over both situations were equal to the situation without naive pigs present

3 The effect of situation within treatment was significant for urinating within the negative treatment, but not within the positive treatment nor for escape attempts and play 